\title{
Rhizomicrobium electricum sp. nov., a facultatively anaerobic, fermentative, prosthecate bacterium isolated from a cellulose-fed microbial fuel cell
}

Correspondence

Kazuya Watanabe

watanabe@light.t.u-tokyo.ac.jp
Yumiko Kodama ${ }^{1}$ and Kazuya Watanabe ${ }^{1,2}$

\author{
${ }^{1}$ Research Center for Advanced Science and Technology, The University of Tokyo, 4-6-1 Komaba, \\ Meguro-ku, Tokyo 153-8904, Japan \\ ${ }^{2}$ Hashimoto Light Energy Conversion Project, Exploratory Research for Advanced Technology, \\ Japan Science and Technology Agency (JST), 7-3-1 Hongo, Bunkyo-ku, Tokyo 113-8656, Japan
}

\begin{abstract}
A facultatively anaerobic, prosthecate bacterium, strain $\mathrm{Mfc} 52^{\top}$, was isolated from a microbial fuel cell inoculated with soil and fed with cellulose as the sole fuel. Cells were Gram-negative, nonspore-forming, straight or slightly curved rods, and some of them had one or two polar prosthecae (stalks). Cells reproduced by binary fission or by budding from mother cells having prosthecae. Strain Mfc52 ${ }^{\top}$ fermented various sugars and produced lactate, acetate and fumarate. Ferric iron, nitrate, oxygen and fumarate served as electron acceptors, while sulfate and malate did not. Nitrate was reduced to nitrite. The DNA G $+\mathrm{C}$ content was $64.7 \mathrm{~mol} \%$. On the basis of $16 \mathrm{~S}$ rRNA gene sequence phylogeny, strain $\mathrm{Mfc}^{2} 2^{\top}$ was affiliated with the genus Rhizomicrobium in the class Alphaproteobacteria and most closely related to Rhizomicrobium palustre with a sequence similarity of $97 \%$. Based on these physiological and phylogenetic characteristics, the name Rhizomicrobium electricum sp. nov. is proposed; the type strain is Mfc52 ${ }^{\top}\left(=\mathrm{JCM} 15089^{\top}\right.$ $=\operatorname{KCTC} 5806^{\top}$ ).
\end{abstract}

Microbial fuel cells (MFCs) are devices that exploit microorganisms to generate electric power from organic matter (Logan et al., 2006; Watanabe, 2008). In our previous study, MFCs were developed with rice-paddy field soil as a source of micro-organisms and crystalline cellulose as the sole fuel, and microbial communities attaching onto graphite anodes in these MFCs were analysed (Ishii et al., 2008a, b). Results showed that rod-shaped members of the class Alphaproteobacteria possessing prosthecae-like appendages (represented by phylotype Mfc-9) were abundantly present in anode biofilm communities (Ishii et al., 2008a), suggesting that they may have played important roles in the cellulose/electricity conversion in these MFCs. In order to investigate their ecological roles, we isolated these bacterial strains (including strain $\mathrm{Mfc} 52^{\mathrm{T}}$ ) and examined their ability to generate electric currents (Kodama \& Watanabe, 2008). It was revealed that strain $\mathrm{Mfc} 52^{\mathrm{T}}$ generated electricity in pureculture MFCs by oxidizing intermediate metabolites (e.g. lactate and acetate) from cellulose degradation, and most cells of strain $\mathrm{Mfc} 52^{\mathrm{T}}$ had long prosthecae similar to those observed in scanning electron micrographs of the anode biofilm in the cellulose-fed MFC (Kodama \& Watanabe, 2008). Strain $\mathrm{Mfc}_{5} 2^{\mathrm{T}}$ is the first isolate of prosthecate

Abbreviation: MFCs, microbial fuel cells.

The GenBank/EMBL/DDBJ accession number for the 16S rRNA gene sequence of strain Mfc52 ${ }^{\top}$ is $\mathrm{AB} 365487$. bacteria with the ability to generate electricity in MFCs. In our phylogenetic analysis (Kodama \& Watanabe, 2008), strain Mfc52 $2^{\mathrm{T}}$ was deeply branched within the class Alphaproteobacteria and closely related to Rhizomicrobium palustre $\mathrm{A} 48^{\mathrm{T}}$, a facultatively anaerobic, fermentative stalked bacterium isolated from rice plant roots (Ueki et al., 2010). In the present study, we performed further physiological and taxonomic analyses of strain $\mathrm{Mfc} 52^{\mathrm{T}}$. Based on the results, we propose that strain $\mathrm{Mfc} 52^{\mathrm{T}}$ represents a novel species in the genus Rhizomicrobium.

Routine cultivation of strain $\mathrm{Mfc} 52^{\mathrm{T}}$ was done without shaking at $30{ }^{\circ} \mathrm{C}$ in $1 / 10$ PYGV medium (Kodama \& Watanabe, 2008) supplemented with $1 \mathrm{~g}$ glucose $\mathrm{l}^{-1}$ under oxygen-free $\mathrm{N}_{2}$ gas in culture bottles capped with Tefloncoated butyl rubber septa and sealed with aluminium crimps. Growth in liquid medium was monitored by measuring optical density at $660 \mathrm{~nm}\left(\mathrm{OD}_{660}\right)$ using a spectrophotometer (U-1100, Hitachi), and cell concentration was determined by directly counting $4^{\prime}$, 6-diamidino-2phenylindole (DAPI)-stained cells under an epifluorescence microscope as described elsewhere (Kodama \& Watanabe, 2003). Cells of Mfc52 $2^{\mathrm{T}}$ were stored at $-80{ }^{\circ} \mathrm{C}$ in liquid $1 / 10$ PYGV medium supplemented with $15 \%(\mathrm{v} / \mathrm{v})$ glycerol.

Cell morphology was examined by transmission electron microscopy (Beveridge et al., 1994). Cells were fixed with glutaraldehyde $(2.5 \%, \mathrm{w} / \mathrm{v})$, negatively stained with 
phosphotungstic acid $(0.2 \%, \mathrm{w} / \mathrm{v})$, and visualized using an H-7000 transmission electron microscope (Hitachi). Motility was checked by phase-contrast microscopy (BX60, Olympus). Gram staining and oxidase/catalase tests were conducted according to standard procedures (Smibert \& Krieg, 1994). The presence of heat-tolerant cells was examined as described by Ueki et al. (2010).

Physiological properties of strain $\mathrm{Mfc} 52^{\mathrm{T}}$ were analysed using $10 \mathrm{ml} 1 / 10$ PYGV medium (without $\mathrm{Na}_{2} \mathrm{CO}_{3}$, $\mathrm{pH} 7.0$ ) or $10 \mathrm{ml}$ BT medium (Kodama \& Watanabe, 2008) in test tubes (30 ml capacity) capped with screw caps tightened with butyl rubber stoppers under oxygen-free $\mathrm{N}_{2}$ gas unless otherwise specified. All following tests were run at least in duplicate. Effects of temperature, $\mathrm{pH}$ and salinity ( $\mathrm{NaCl}$ concentration) on bacterial growth were examined in $1 / 10$ PYGV medium supplemented with 1 g glucose $1^{-1}$. Aerobic growth was examined on nutrient agar (Difco) and 1/10 PYGV agar plates without cysteine and $\mathrm{Na}_{2} \mathrm{CO}_{3}$. Fermentative growth was examined in BT medium with substrates added at $10 \mathrm{~g} \mathrm{l}^{-1}$ (for sugars and sugar alcohols) or $20 \mathrm{mM}$ (organic acids, amino acids and alcohols). Utilization of electron acceptors was tested in BT medium supplemented with $1 \mathrm{~g}$ glucose $1^{-1}$ as sole carbon source and $\mathrm{Na}_{2} \mathrm{SO}_{4}, \mathrm{NaNO}_{3}$, ferric citrate, sodium fumarate, sodium DL-malate (each at $10 \mathrm{mM}$ ) or $\mathrm{O}_{2}$ (head-space $\mathrm{N}_{2}$ gas replaced with air) as sole electron acceptor. The Fe(III)reducing ability of strain $\mathrm{Mfc} 52^{\mathrm{T}}$ was examined in BT medium in the presence of $10 \mathrm{mM}$ ferric citrate with glucose $\left(2 \mathrm{~g} \mathrm{l}^{-1}\right)$, acetate, pyruvate, lactate, succinate, propionate, formate, ethanol (each at $10 \mathrm{mM}$ ) or $\mathrm{H}_{2}$ [headspace replaced with $\mathrm{H}_{2} / \mathrm{CO}_{2}(80 / 20 \%)$ gas] as the sole electron donor. Organic acids were analysed by highperformance liquid chromatography (HPLC) as described by Ishii et al. (2008a). Glucose concentration was determined using F-kit (R-Biopharm) according to the manufacturer's instructions. $\mathrm{H}_{2}, \mathrm{CO}_{2}$ and $\mathrm{O}_{2}$ in the head space were measured by gas chromatography as described elsewhere (Ishii et al., 2005). Concentrations of nitrate, nitrite and sulfate were determined by using an ion chromatograph (ICA-2000, DKK-TOA) equipped with an electrolytic conductivity detector and a spectrophotometer. Ferrous iron concentration was determined by the ferrozine method (Stookey, 1970).

Cellular fatty acids and quinones were analysed by TechnoSuruga Laboratory, Shimizu, Japan. The DNA $\mathrm{G}+\mathrm{C}$ content was determined by an HPLC method according to Katayama-Fujimura et al. (1984). The almost-full-length $16 \mathrm{~S}$ rRNA gene was sequenced previously (Kodama \& Watanabe, 2008). A search of the GenBank database was carried out by using the BLAST program (Altschul et al., 1990). Multiple alignments of the sequences were conducted using the CLUSTAL W program (Thompson et al., 1994). A phylogenetic tree was reconstructed by the neighbour-joining method (Saitou \& Nei, 1987) using the MEGA4 program (Tamura et al., 2007). Positions where any sequence had a gap or ambiguous nucleotide were not included in the calculation.
Colonies of strain $\mathrm{Mfc} 52^{\mathrm{T}}$ on 1/10 PYGV and 1/10 GA agar plates (Kodama \& Watanabe, 2008) were translucent and thin with smooth surfaces. Cells were Gram-negative, straight or slightly curved rods $(0.9-2.5 \mu \mathrm{m}$ long and $0.2-$ $0.3 \mu \mathrm{m}$ wide). They occurred singly or in pairs connected by constrictions, and some of them had one or two polar prosthecae (Fig. 1). Sizes of prosthecae were up to $3 \mu \mathrm{m}$ in length and 80 to $110 \mathrm{~nm}$ in diameter. Some prosthecae had branched structures at the tips (Fig. 1a). Cells reproduced by binary fission or by budding from mother cells with prosthecae. They were motile by means of single polar flagella. Catalase and oxidase activity were not detected. Strain Mfc52 ${ }^{\mathrm{T}}$ did not produce heat-tolerant cells. Growth of strain $\mathrm{Mfc} 52^{\mathrm{T}}$ was observed between $15{ }^{\circ} \mathrm{C}$ and $40{ }^{\circ} \mathrm{C}$, with optimum growth at $30{ }^{\circ} \mathrm{C}$, and between $\mathrm{pH} 5.0$ and 7.5 with optimum growth at $\mathrm{pH}$ 6.7. Strain $\mathrm{Mfc} 52^{\mathrm{T}}$ grew with 0 to $1.0 \%(\mathrm{w} / \mathrm{v}) \mathrm{NaCl}$, optimum $0.5 \%(\mathrm{w} / \mathrm{v}) \mathrm{NaCl}$. Aerobic growth was observed on agar plates. Strain $\mathrm{Mfc} 52^{\mathrm{T}}$ also grew fermentatively (see species description). Major fermentation products from glucose were lactate $\left(4.5 \mathrm{mmol} \mathrm{l}^{-1}\right)$, acetate $\left(3.6 \mathrm{mmol} \mathrm{l}^{-1}\right)$ and fumarate (3.4 mmol ${ }^{-1}$ ), and small amounts of $\mathrm{CO}_{2}$ and $\mathrm{H}_{2}$ were also produced. We found that oxygen, nitrate, fumarate and $\mathrm{Fe}(\mathrm{III})$ were utilized as electron acceptors in the presence of glucose, while sulfate and malate were not. Nitrite was the final product of nitrate reduction. Fe(III) was not reduced with acetate, lactate, succinate, pyruvate, formate, propionate, ethanol or $\mathrm{H}_{2}$ as sole electron donor. Strain $\mathrm{Mfc} 2^{\mathrm{T}}$ generated electricity by oxidizing organic acids (lactate and acetate) in an MFC reactor (Kodama \& Watanabe, 2008).

The fatty acids $(>0.1 \%)$ of strain $\mathrm{Mfc} 52^{\mathrm{T}}$ were $\mathrm{C}_{18: 1} \omega 7 c$ $(47.3 \%)$, anteiso- $\mathrm{C}_{15: 0}(14.0 \%), \mathrm{C}_{16: 0}(8.6 \%)$, iso- $\mathrm{C}_{15: 0}$ (7.6\%), $\mathrm{C}_{16: 0} 3-\mathrm{OH}(3.0 \%), \mathrm{C}_{14: 0}(2.7 \%), 11$-methyl $\mathrm{C}_{18: 1} \omega 7 c(2.7 \%), \mathrm{C}_{18: 0}(2.6 \%)$, iso- $\mathrm{C}_{14: 0}(2.2 \%)$, iso$\mathrm{C}_{17: 0} 3-\mathrm{OH}(1.2 \%), \mathrm{C}_{17: 0} 2-\mathrm{OH}(1.1 \%)$, iso- $\mathrm{C}_{15: 0} 2-\mathrm{OH}$ and/or $\mathrm{C}_{16: 1} \omega 7 c(0.8 \%)$, iso- $\mathrm{C}_{17: 0} \quad(0.7 \%), \mathrm{C}_{18: 1} \omega 9 c$ $(0.7 \%)$, iso- $\mathrm{C}_{16: 0} 3-\mathrm{OH}(0.6 \%)$, iso- $\mathrm{C}_{16: 1} \mathrm{I}$ and/or $\mathrm{C}_{14: 0}$ $3-\mathrm{OH}(0.6 \%)$, anteiso- $\mathrm{C}_{17: 0}(0.5 \%)$, iso- $\mathrm{C}_{16: 0}(0.5 \%)$, iso- $\mathrm{C}_{15: 0} 3-\mathrm{OH}(0.5 \%), \mathrm{C}_{13: 1}$ AT 12-13 (0.4\%), $\mathrm{C}_{20: 1} \omega 7 c$
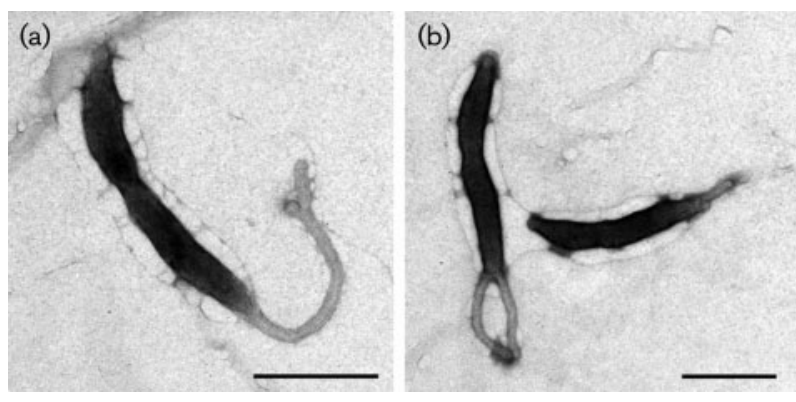

Fig. 1. Transmission electron micrographs of strain $\mathrm{Mfc} 2^{\top}$ cultivated for 4 days on 1/10 PYGV medium, showing a polar prostheca with a tip-branched structure (a) and the development of two polar prosthecae (b). Bars, $1 \mu \mathrm{m}$. 
(0.4\%), 10-methyl $\mathrm{C}_{19: 0}(0.3 \%), \mathrm{C}_{18: 0} 3-\mathrm{OH}(0.3 \%), 10-$ methyl $\mathrm{C}_{16: 0}(0.3 \%), \mathrm{C}_{18: 1} 2-\mathrm{OH}(0.3 \%)$ and $\mathrm{C}_{17: 0}$ $(0.2 \%)$. The predominant respiratory quinone was ubiquinone Q-10. The genomic DNA G $+\mathrm{C}$ content of strain $\mathrm{Mfc} 52^{\mathrm{T}}$ was $64.7 \mathrm{~mol} \%$.

A database search based on the 16S rRNA gene sequence of strain $\mathrm{Mfc} 52^{\mathrm{T}}$ revealed that it was most closely related to environmental clone RB521 (97.8\% sequence similarity) that was retrieved from rhizosphere biofilm in a reed bed reactor. The second closest relative was Rhizomicrobium palustre $\mathrm{A} 48^{\mathrm{T}}(97.3 \%)$, isolated from roots of rice plants grown in flooded rice field soil (Ueki et al., 2010). Other sequences in the databases were not highly similar; e.g. the third and fourth closest relatives were Pleomorphomonas oryzae strain DSM $16300^{\mathrm{T}}(87.8 \%)$, a nitrogen-fixing bacterium isolated from rice (Xie \& Yokota, 2005) and Methylocystis parvus NCIMB $11129^{\mathrm{T}}(87.6 \%)$, a methanotroph belonging to the family Methylocystaceae in the order Rhizobiales (Bowman et al., 1993). 16S rRNA gene sequence similarities with other bacteria in the class Alphaproteobacteria were less than $85 \%$; e.g. Sphingomonas paucimobilis ATCC $29837^{\mathrm{T}}(84.9 \%)$, Caulobacter vibrioides DSM $9893^{\mathrm{T}}(84.6 \%)$, Kordiimonas gwangyangensis JCM $12864^{\mathrm{T}}(84.7 \%)$ and Hyphomonas polymorpha DSM $2665^{\mathrm{T}}(81.3 \%)$. Strain $\mathrm{Mfc5} 2^{\mathrm{T}}$ and $R$. palustre $\mathrm{A} 48^{\mathrm{T}}$ clustered together to form a distinct branch within the class Alphaproteobacteria (Fig. 2). They were most closely related to the order Rhizobiales but seemed not to be affiliated with any established order in the class Alphaproteobacteria. We also found that some important characteristics of strains $\mathrm{A} 48^{\mathrm{T}}$ and $\mathrm{Mfc} 52^{\mathrm{T}}$ were different from those of the related genera Pleomorphomonas and Methylocystis in the order Rhizobiales; for instance, members of these genera are aerobic and do not have prostheca (Xie \& Yokota, 2005; Bowman et al., 1993). Further studies will be needed to identify whether a novel order should be proposed for strains $\mathrm{A} 48^{\mathrm{T}}$ and $\mathrm{Mfc} 52^{\mathrm{T}}$.

R. palustre $\mathrm{A} 48^{\mathrm{T}}$ was isolated from rice plant roots (Ueki et al., 2010), and closely related sequences were also retrieved from the anode of a sediment MFC submerged in a rice rhizosphere (Kaku et al., 2008), suggesting that the bacterial group represented by strain $\mathrm{A} 48^{\mathrm{T}}$ ( $R$. palustre) thrives in rhizospheres. In contrast, strain $\mathrm{Mfc} 52^{\mathrm{T}}$ was isolated from an MFC bioreactor (Kodama \& Watanabe, 2008). In addition to their habitats, we also found several distinct features that could clearly differentiate strain $\mathrm{Mfc} 52^{\mathrm{T}}$ from $R$. palustre (Table 1); these features include the number and tip structure of prosthecae, DNA G $+\mathrm{C}$ content, abilities to utilize nitrate and fumarate as electron acceptors, sugarutilization pattern, fermentative products from glucose, $\mathrm{C}_{18: 1} \omega 7 \mathrm{c}$ content and minor fatty-acid composition. From these results and the 16S rRNA gene sequence comparison, strain $\mathrm{Mfc} 52^{\mathrm{T}}$ is considered to represent a novel species in the genus Rhizomicrobium, for which the name Rhizomicrobium electricum sp. nov. is proposed.

\section{Description of Rhizomicrobium electricum sp. nov.}

Rhizomicrobium electricum [e.lec'tri.cum. L. n. electrum amber; L. suff. -icus $-a-u m$ suffix used with the sense of pertaining to; N.L. neut. adj. electricum referring to generation of electricity (a physical force so called because it first was generated by rubbing amber)].

Cells are Gram-negative, non-spore-forming, straight or slightly curved rods, $0.9-2.5 \mu \mathrm{m}$ long and $0.2-0.3 \mu \mathrm{m}$ wide. Some cells have one or two polar prosthecae with tipbranched structures. Prosthecae are $\sim 3 \mu \mathrm{m}$ in length and $80-110 \mathrm{~nm}$ in diameter. Cells reproduce by budding from

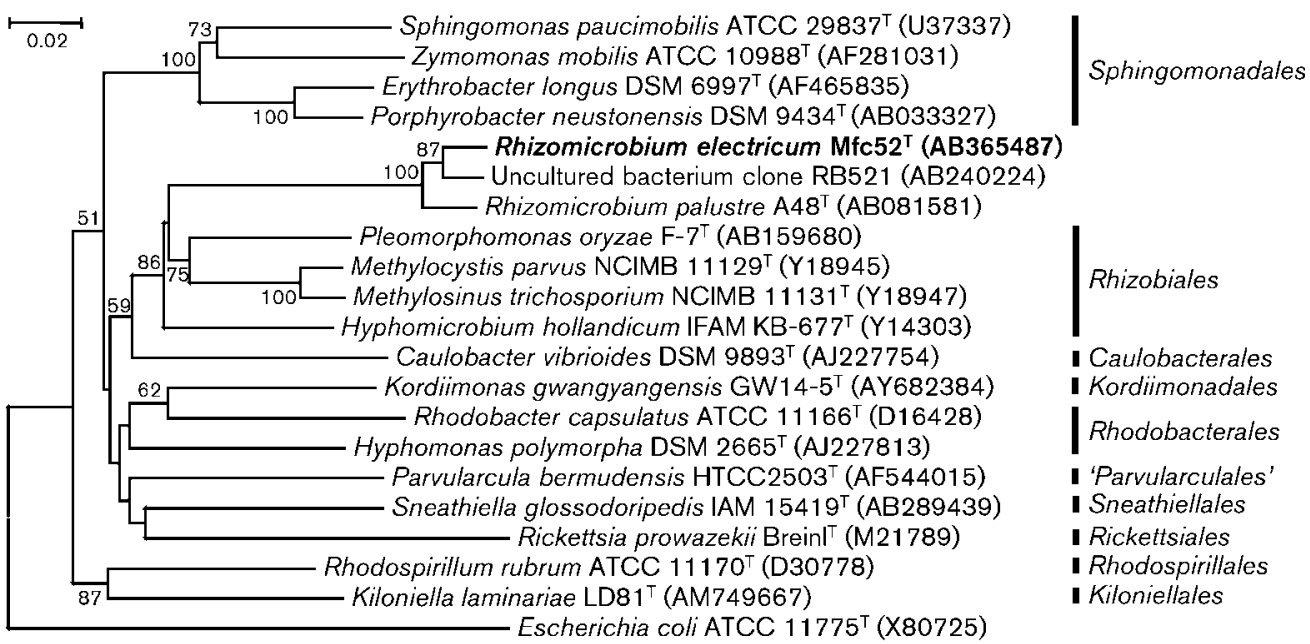

Fig. 2. Neighbour-joining tree based on $16 \mathrm{~S}$ rRNA gene sequences showing the position of strain $\mathrm{Mfc}_{5} 2^{\top}$ in the class Alphaproteobacteria. Escherichia coli was used as the outgroup. Accession numbers of sequences retrieved from the databases are given in parentheses. Numbers at branch nodes are bootstrap values (per 100 trials); only values greater than 50 are shown. Bar, 0.02 substitutions per site. 
Table 1. Differences in characteristics of strain $\mathrm{Mfc} 2^{\top}$ and R. palustre $\mathrm{A} 48^{\top}$

+, Positive; -, negative; A, acetate; E, ethanol; F, fumarate; L, lactate.

\begin{tabular}{|c|c|c|}
\hline Characteristic & $\operatorname{Mfc} 52^{\mathrm{T}}$ & R. palustre $\mathrm{A}_{48} \mathrm{~T}^{\mathrm{T}_{\star}}$ \\
\hline Tip structure of prosthecae & Straight or branched & Straight or holdfast-like \\
\hline Number of prosthecae & One or two & One \\
\hline DNA G $+\mathrm{C}$ content $(\mathrm{mol} \%)$ & 64.7 & 55.4 \\
\hline \multicolumn{3}{|c|}{ Anaerobic growth on glucose by reduction of: } \\
\hline Nitrate & + (reduced to nitrite) & - \\
\hline Fumarate & + & - \\
\hline \multicolumn{3}{|l|}{ Fermentative growth on: } \\
\hline Ribose & + & - \\
\hline Mannose & + & - \\
\hline Trehalose & + & - \\
\hline Raffinose & + & - \\
\hline Pyruvate & + & - \\
\hline Xylan & - & + \\
\hline Fementation products $\left(\mathrm{mol} \mathrm{l}^{-1}\right)$ & $\mathrm{L}(4.5), \mathrm{A}(3.6), \mathrm{F}(3.4) \dagger$ & $\mathrm{L}(10.4), \mathrm{E}(5.1), \mathrm{A}(4.1) \dagger$ \\
\hline Major fatty acids (\%) & $\begin{array}{c}\mathrm{C}_{18: 1} \omega 7 c(47.3), \text { anteiso- } \mathrm{C}_{15: 0}(14.0) \\
\mathrm{C}_{16: 0}(8.6)\end{array}$ & $\begin{array}{c}\mathrm{C}_{18: 1} \omega 7 c(29.4), \text { anteiso- } \mathrm{C}_{15: 0}(16.2) \\
\mathrm{C}_{16: 0}(13.2)\end{array}$ \\
\hline
\end{tabular}

${ }^{\star}$ Data from Ueki et al., 2010.

$\dagger$ Small amouts of $\mathrm{CO}_{2}$ and $\mathrm{H}_{2}$ were also produced.

a mother cell having prosthecae. Motile by single polar flagella. Catalase- and oxidase-negative. Facultatively anaerobic. The optimum growth temperature is $30{ }^{\circ} \mathrm{C}$ (range $15-$ $40{ }^{\circ} \mathrm{C}$ ), the optimum $\mathrm{pH}$ is 6.7 (range 5.0-7.5), and the optimum $\mathrm{NaCl}$ concentration for growth is $0.5 \%(\mathrm{w} / \mathrm{v})$ (range $0-1.0 \%, \mathrm{w} / \mathrm{v}$ ). Aerobic growth is observed on nutrient agar and 1/10 PYGV agar plates. Utilizes glucose, galactose, arabinose, xylose, cellobiose, maltose, lactose, sucrose and soluble starch as fermentative substrates. Slow growth (lag phase continues for 10 days or longer) is observed on rhamnose, raffinose, mannose, fructose, ribose, trehalose and pyruvate. Major fermentation products of glucose are lactate, acetate and fumarate. Does not utilize lactate, malate, fumarate, succinate, citrate, glycine, serine, alanine, glutamate, aspartate, xylan, sorbose, cellulose, glycerol, inositol, mannitol, sorbitol, ethanol, methanol or propanol. Utilizes oxygen, nitrate, $\mathrm{Fe}$ (III) and fumarate as electron acceptors in the presence of glucose. Nitrate is reduced to nitrite. Sulfate and malate are not utilized as electron acceptors. The major cellular fatty acids are $\mathrm{C}_{18: 1} \omega 7 c$, anteiso- $\mathrm{C}_{15: 0}, \mathrm{C}_{16: 0}$ and iso- $\mathrm{C}_{15: 0}$. The predominant respiratory quinone is ubiquinone Q-10. The genomic DNA G $+C$ content of the type strain is $64.7 \mathrm{~mol} \%$.

The type strain, Mfc52 $2^{\mathrm{T}}$ (=JCM $15089^{\mathrm{T}}=\mathrm{KCTC} 5806^{\mathrm{T}}$ ), was isolated from biofilm attached to anode graphite of a cellulose-fed microbial fuel cell.

\section{Acknowledgements}

We thank Midori Satoh for technical assistance. We also thank Professor H. G. Trüper for his help with the Latin nomenclature. This work was supported by Japan Society for Promotion of Science (JSPS).

\section{References}

Altschul, S. F., Gish, W., Miller, W., Myers, E. W. \& Lipman, D. J. (1990). Basic local alignment search tool. J Mol Biol 215, 403-410.

Beveridge, T. J., Popkin, T. J. \& Cole, R. M. (1994). Electron microscopy. In Methods for General and Molecular Bacteriology, pp. 42-71. Edited by P. Gerhardt, R. G. E. Murray, W. A. Wood \& N. R. Krieg. Washington, DC: American Society for Microbiology.

Bowman, J. P., Sly, L. I., Nichols, P. D. \& Hayward, A. C. (1993). Revised taxonomy of the methanotrophs: description of Methylobacter gen. nov., emendation of Methylococcus, validation of Methylosinus and Methylocystis species, and a proposal that the family Methylococcaceae includes only the group I methanotrophs. Int J Syst Bacteriol 43, 735-753.

Ishii, S., Kosaka, T., Hori, K., Hotta, Y. \& Watanabe, K. (2005). Coaggregation facilitates interspecies hydrogen transfer between Pelotomaculum thermopropionicum and Methanothermobacter thermautotrophicus. Appl Environ Microbiol 71, 7838-7845.

Ishii, S., Shimoyama, T., Hotta, Y. \& Watanabe, K. (2008a). Characterization of a filamentous biofilm community established in a cellulose-fed microbial fuel cell. BMC Microbiol 8, 6 .

Ishii, S., Hotta, Y. \& Watanabe, K. (2008b). Methanogenesis versus electrogenesis: morphological and phylogenetic comparisons of microbial communities. Biosci Biotechnol Biochem 72, 286-294.

Kaku, N., Yonezawa, N., Kodama, Y. \& Watanabe, K. (2008). Plant/ microbe cooperation for electricity generation in a rice paddy field. Appl Microbiol Biotechnol 79, 43-49.

Katayama-Fujimura, Y., Komatsu, Y., Kuraishi, H. \& Kaneko, T. (1984). Estimation of DNA base composition by high performance liquid chromatography of its nuclease P1 hydrolysate. Agric Biol Chem 48, 3169-3172.

Kodama, Y. \& Watanabe, K. (2003). Isolation and characterization of a sulfur-oxidizing chemolithotroph growing on crude oil under anaerobic conditions. Appl Environ Microbiol 69, 107-112. 
Kodama, Y. \& Watanabe, K. (2008). An electricity-generating prosthecate bacterium strain Mfc52 isolated from a microbial fuel cell. FEMS Microbiol Lett 288, 55-61.

Logan, B. E., Hamelers, B., Rozendal, R., Schröder, U., Keller, J., Freguia, S., Aelterman, P., Verstraete, W. \& Rabaey, K. (2006). Microbial fuel cells: methodology and technology. Environ Sci Technol 40, 5181-5192.

Saitou, N. \& Nei, M. (1987). The neighbor-joining method: a new method for reconstructing phylogenetic trees. Mol Biol Evol 4, 406-425.

Smibert, R. M. \& Krieg, N. R. (1994). Phenotypic characterization. In Methods for General and Molecular Bacteriology, pp. 607-655. Edited by P. Gerhardt, R. G. E. Murray, W. A. Wood \& N. R. Krieg. Washington, DC: American Society for Microbiology.

Stookey, L. L. (1970). Ferrozine - a new spectrophotometric reagent for iron. Anal Chem 42, 779-781.
Tamura, K., Dudley, J., Nei, M. \& Kumar, S. (2007). MEGA4: molecular evolutionary genetics analysis (MEGA) software version 4.0. Mol Biol Evol 24, 1596-1599.

Thompson, J. D., Higgins, D. G. \& Gibson, T. J. (1994). CLUSTAL W: improving the sensitivity of progressive multiple sequence alignment through sequence weighting, position-specific gap penalties and weight matrix choice. Nucleic Acids Res 22, 4673-4680.

Ueki, A., Kodama, Y., Kaku, N., Shiromura, T., Satoh, A., Watanabe, K. \& Ueki, K. (2010). Rhizomicrobium palustre gen. nov., sp. nov., a facultatively anaerobic, fermentative stalked bacterium in the class Alphaproteobacteria isolated from rice plant roots. J Gen Appl Microbiol 56, 193-203.

Watanabe, K. (2008). Recent developments in microbial fuel cell technologies for sustainable bioenergy. J Biosci Bioeng 106, 528-536.

Xie, C.-H. \& Yokota, A. (2005). Pleomorphomonas oryzae gen. nov., sp. nov., a nitrogen-fixing bacterium isolated from paddy soil of Oryza sativa. Int J Syst Evol Microbiol 55, 1233-1237. 